\title{
Practice of UNCLOS between Developing Countries with Refer- ence to the Conflict over the South Talpatty Island
}

\author{
By M. Habibur Rahman
}

\section{Introduction}

The Law of the Sea has developed over the years, and is presently codified in the United Nations Convention on the Law of the Sea, $1982^{1}$ (LOS Convention), which was the outcome of the Third United Nations Conference on the Law of the Sea. The approach of this paper is to deal with the trends of the developing countries in safeguarding their interests in the sea zones within national jurisdiction, and it will focus on the insight of the convention provisions. Efforts will be made to become acquainted with the LOS practices of developing countries. Specifically, the study will clarify the Bangladesh LOS practice. It will critically deal with the problems of deciding on the ownership of nnewborn" islands in the maritime zones beyond the territorial sea. With regard to the conflict over the ownership of the South Talpatty Island, the study will go into the reality of the problem between Bangladesh and India.

\section{Developing Countries: what for in LOS Matters?}

Everyone works for his own interests. Almost in every context this proposition is applicable. In sea matters, there is no exception to this proposition. To secure its interests, a coastal state usually wants unquestioned authority over the waters adjacent to his coast. As the sovereignty of the coastal state extends to the internal waters, every state wishes to enclose a large area of waters by baselines. In this respect the trends of the developing or the developed coastal states are similar.

In addition to its land territory, and internal waters, the sovereignty of a coastal state extends to the territorial sea. Significant is the fact that no other state can challenge the coastel state on the question of sovereignty to the territorial sea. When subject to innocent passage, the other state is only entitled to navigate through the territorial sea of the coastal state. The warships will have to comply with the innocent passage criteria. It is, therefore, not favourable for the imperialist and industrialist states for their warships to claim wide territorial seas. This clarifies why the imperialist and the industrialist nations prefer a narrow territorial sea. The poor developing countries want a broader

1 UNDocA/CONF/62/121, 21 Oct 1982

2 See note 1 above. 
territorial sea. The purpose of this is to safeguard its interests from the unscrupulous attempts of the alien states.

The long standing territorial sea breadth limit problem seems to have been solved by the 12-nautical mile limit (Art. 12 Los Convention). But it cannot be said that there will prevail uniformity among the coastal states as to the breadth limit of the territorial sea. It is mentionable that some Latin American states, such as Chile, Ecuador and Peru, since 1952 proclaimed national sovereignty over the 200 mile sea zone. ${ }^{3}$ States like Brasil (1970), Ecuador (1966) and Panama (1967) adopted 200-mile territorial sea. ${ }^{4}$ As time passed, some developing countries claimed a 200-mile territorial sea. ${ }^{5}$ Since 1974 twelve states appear to have been claiming a territorial sea in excess of 12 miles. $^{6}$

As the regime of the Exclusive Economic zone (EEZ) coastal states to explore and exploit the living and non-living resources, it is then from the economic point of view all the same whether the $200 \mathrm{n} . \mathrm{m}$. sea zone is taken as the EEZ or the territorial sea. However, since some coastal states want their sovereignty to be unquestioned, they prefer to adopt a 200 n.m. territorial sea.

It is noticeable that these states belong to the group of developing countries. Though, in the emergence of the EEZ, the developing countries' contributions are unquestioned, some developing countries see their interest secured best by a territorial sea than an EEZ.

As regards the emergence of the continental shelf, the contributions of the industrialised states are significant. In connection with the exploration of the continental shelf and exploitation of its mineral resources much more expertise, technology and capital are required than required for exploring and exploiting the living resources. From this observation it may be noted that the continental shelf regime would - in practice - be limited to the industrialised states. But the states' practice was different to the fact that, while the continental shelf first was adopted by the United States through its Truman Proclamation 1945, the undeveloped states were not behind in adopting the shelf in their enactments. The undeveloped states did not take into account, whether it would be feasible for them to explore the shelf and exploit its natural resources though having no capital, technology and expertise necessary to that end. But the trends of these states in proclaiming the continental shelf were no different from those of the industrialised states

3 Agreements between Chile, Ecuador and Peru signed at the First Conference on the Exploitation and Conservation of the Maritime Resources of the South Pacifics, Santiago, 18 August 1952, were ratified by all signatory states. Costa Rica became a party by accession. See UnLeg.Ser. ST/LLG/SER.B/6(1957) 723.

4 See L.D.M. Nelson, "The Patrimonial Sea", 22(1973) International and Comparative Law Quarterly (London) 678, 679.

5 See note 10 below.

6 E.g. Angola (20:1975), Argentina (200:1977), Benin (200:1976), Cameroon (200:1974), Cape Verde (100:1977), Congo (200:1977), Ghana (200:1977), Guinea Bissau (150:1974), Liberia (200:1977), Senegal (150:1976), Colombia (200:1975), El Salvador (200:1976), See Robert B. Krueger \& Nyron H. Nordquist, "The Evolution of the 200-Hile Exclusive Economic Zone: State Practice in the Pacific Basin", 19(1978-79) Virginia Journal of International Law 321-400. 
and it may be said that the developing states' continental shelf enactments have helped to make these states legally safer from the unscrupulous attempts of the industrialised states. Independent of the question of technical feasibility, the proclamation of the continental shelf secures the authority over the exploitation of its natural resources. Considering the trends of the developing countries with regard to all sea zones, the legal protection of their interests plays a primary role.

\section{3. "New-Born" Islands: A Deal of Corflict}

Islands of any size may exist near and off the coast. It may be made of muds, rocks or of any components. The LOS Convention has made provision for an island to claim a territorial sea, a contiguous zone, an EEZ and a continental shelf. ${ }^{7}$ This is irrespective of the size of the island. Specifically speaking, an island with a radius of 7 miles can have an area of 154 square miles. The area of its 200-mile EEZ will be about 133,533 square miles. If the continental shelf extends beyond 200 miles, the island can claim a larger area of seabed and subsoil. ${ }^{8}$

With the help of science and technology, it is not impossible to envisage a state, particularly a developed state, making any island or rock formation habitable. If the resources of the EEZ and continental shelf are sufficiently attractive, there is all the more reason for such a state to embark on steps to establish its claim over unclaimed or emerging islands and rocks. Therefore, Article 121 fo the LOS Convention as it stands today is a recipe for confusion and conflict. A question which has arisen and which has not been answered yet, is: which state is entitled to assume sovereignty over an island, which it is formed in the EEZ or continental shelf? The provisions in the LOS Convention on the EEZ and continental shelf do not address this specific question. But if we say that a state can only assert sovereignty over islands within its territorial sea, this would mean that islands beyond its territorial sea, but within its EEZ or on its continental shelf, shall be treated just as islands in the high seas. And sovereignty per se will have to be based on claims of effective occupation and so forth.

Another problem which can arise is as follows. According to Article 77(3) of the LOS Convention, the rights of the coastal state over the continental shelf "do not depend on occupation, effective or national, or on any express proclamation". But what is the position if an island occupied by state $A$ rises form what is claimed by state B as its continental shelf? It would seem that if state A can show effective occupation, state B

7 Art 121.

8 Mathematically, the area. of a circle with a 7 -mile radius is calculated thus: $22 / 7 \times 7^{2}=154$ square miles. The area of such a circle with a 12 -mile territorial sea is $22 / 7 \times(7+12)^{2}=1,135$ square miles. But the area of the territorial sea is $1,135-154=981$ square miles. The area of the same circle with a $200-$ mile EEZ is $22 / 7 \times 207^{2}=134,668$ square miles. Therefore, the area of the EEZ is $134,668-1,135=133,533$ square miles. 
will have no claim to the island at all, if all it can show is the fact that it is the coastal state. Since the LOS Convention is silent on the resolution of such a conflict, one has to refer to customary international law and depend on the occupation criterion for a solution.

Before the emergence of the regime of the continental shelf or EEZ, the coastal state was entitled to safeguard its interests only in its territorial sea. With the introduction of these two new regimes, coastal states now find themselves entitled to sovereign economic rights in extended areas. That being the case, it is foreseable that non-coastal states may wish to assert territorial claims to islands by sheer physical force, especially if their resources are worthwhile, at the expence of their smaller and weaker neighbours.

The LOS Convention and the Convention on the Continental Shelf ${ }^{9}$ are silent on the question of territorial sovereignty over the continental shelf and the EEZ. Instead, they refer to the fact that coastal states may exercise sovereign rights over the resources only that are found in those areas. By their silence on the matter of territorial sovereignty one can only assume that if a state wishes, there is nothing to stop it from adopting measures for the establishment of territorial sovereignty over islands which appear in these areas. So far, it would seem that only fourteen states have claimed a 200 nautical mile territorial sea. ${ }^{10}$ Such a claim would incorporate the area of an EEZ or continental shelf, as the case may be. Examples of explicit claims to territorial sovereignty over the continental shelf are seen in the proclamations by Australia (1955), Bahamas (1948), Chile (1947), Costa Rica (1948), Honduras (1950), Jamaica (1948), Korea (1952), Mexico (1945), Nicaragua (1950), Pakistan (1950) and the British Protected Arab Sheikhdoms (1949). ${ }^{11}$ As these examples are claims to territorial sovereignty in the continental shelf, island found therein would automatically be part of the territory of the claimant coastal state. This dispenses with the need to show effective occupation before territorial sovereignty can be established. But what of new-born islands beyond such areas, or islands which emerge in the EEZ or continental shelf of a state but beyond an area claimed by it to be under its territorial sovereignty? The answer cannot be found in the Convention, unfortunately.

Before the emergence of the continental shelf doctrine, the coastal state was entitled to safeguard its interests in the territorial sea. But, from the economic point of view, the coastal state can safeguard its interests in the EEZ and the continental shelf better than in the territorial sea; according to the LOS Convention, the coastal state is entitled to exercise sovereign rights over the resources in the EEZ and the continental shelf. In this regard, not state can overlap the coastal state's claims.

9 UNDocA/CONF/13/L55(1958).

10 E.g. Argentina (1977), Bein (1970), Brazil (1970), Cameroon (1974), Colombo (1975), Congo (1977), Ecuador (1966), El Salvador (1976), Ghana (1977), Guinea (1965), Liberia (1977), Peru (1947), Sierra Leone (1971), Somalia (1972), See n.6 above at 390-399 and 8(1969) International Legal Materials 516-554.

11 E.g. Abu Dhabi, Ajman, Bahrain, Dubai, Kuwait, Ras-el-Khaimah, Sharja and Ummal Qaywayn.

12 See LOS Convention, Art 77. 
It would, then, not be rational to substantiate the claims of a foreign state over islands formed in the EEZ or the continental shelf against the coastal state. If the "occupation" criterion is the deciding factor, the ownership of the islands would be subject to physical force. It would therefore be easy for the big and strong state to assert claims by physical force against its small, weak neighbour.

At present the regime of the continental shelf deals with the seabed and subsoil beyond the 200-mile EEZ, because within the 200-mile EEZ, whether the continental shelf exists or does not exist, the coastal state is entitled to explore the seabed and subsoil and exploit its resources, both living and non-living. Neither the Continental Shelf Convention nor the LOS Convention states whether it is possible for the coastal state to assert claims to the continental shelf or the EEZ as belonging to its territory. However, by implication, ${ }^{13}$ it seems that the coastal state may exercise rights over the resources only. In other words, neither the Continental Shelf Convention nor the LOS Convention has given authority to the coastal state to regard the continental shelf or the EEZ as part of its sovereign territory. On the other hand, the Convention has not adopted any specific provisions against the assertion of claims to the continental shelf and the EEZ as belonging to the territory of the coastal state. Failure to make specific provision leads to the assumption that measures, if taken by the coastal state to assert claims to the continental shelf and the EEZ as belonging to its territory, will not be a violation of the Convention.

If an island emerges in the sea zone claimed as the territorial sea or on the seabed claimed to be under the territorial sovereignty, the island will automatically be the part of the coastal state. Clearly speaking, an island if formed in the coastal sea such as the 200-mile territorial sea or on the seabed claimed as under the territorial sovereignty of the states, these states have no problem to assert claims to such island on the assumption that it is a part of its territory. As seen, the states which need assert claims to the islands emerged in the extended sea zone belong to the group of developing countries. In the case of developed states, it can be said that they want extended seabed jurisdiction, but they do not want the continental shelf to be regarded as lying under the territorial sovereignty. There is no problem for these states to assert claims to the new-born island whether on the continental shelf or in the high seas even.

But it is a big problem for asserting claims to such island on the EZZ or the continental shelf by the poor developing countries. It is therefore, the poor and weak developing countries' aim at protecting the interests by asserting claims to the islands as part of its territory. Though the LOS Convention fails to decide the status of a "new-born " island which surfaces in the EEZ and on the continental shelf, it will not be a missing for the poor and weak developing countries to take measures for claiming the islands so emerged. In so doing, these states must be careful in adopting provision for sea concerns. That is to say, it is generally necessary for every state to comply with the LOS provisions

13 See Continental Shelf Convention, Arts 2,3; LOS Convention, Arts 77, 78. 
but basically the needs must be taken into account for protecting its own interests. In any case the LOS Convention fails to decide the status of a new-born island which has surfaced beyond the territorial sea.

\section{Bangladesh and India on the South Talpatty Island}

As adjacent coastal states, every sea zone is to be delimited between Bangladesh and India. The configuration of the coast of Bangladesh is concave, but the same of India adjoining the Bay of Bengal is convex. The delimitation of sea zones involves a conflict of interest between Bangladesh and her neighbours. The issues of conflict arose mainly with India when in 1974 the Government of Bangladesh signed production sharing contracts with six oil companies granting them exploration rights of oil and natural gas in her territorial waters in the Bay of Bengal.

In this respect the Bangladesh line moved toward the south from the end of its land boundary, while the Indian line took a south-easterly direction creating an angle within which lies thousands of square miles of the bay claimed by each country as its economic zone. It has become the all important matter for Bangladesh and India on which will depend their areas of authority in the seas for example, in the form of the territorial sea, EEZ and the continental shelf. Though negotiations have been going on since 1974, Bangladesh and India have not been able to settle the problem of delimination to the concave nature of the Bangladesh coast.

Bangladesh's position is that no rigid principle can be applied in the present case. The basic guideline is equity. India, on the other hand, attempts to apply the principle of requidistancer in delimiting the boundary ignoring the physical features of the coast. Furthermore, it is important to mention that new islands are rising in the coastal bay. By this time, the ownership of the newly emerged island(s) such as South Talpatty/New Moore/Purbasha in the estuary of the border river Haribhanga between Bangladesh and India has been claimed both by Bangladesh and India as forming part of their respective territories. The boundary between Bangladesh and India in this area is the midstream of the main channel of the border river Haribhanga.

The island was formed in the estuary of the border river Haribhanga and the internal river Raimangal most probably after the cyclone and tidal bore of 1970, it being a new land rising initially as a low-tide elevation. ${ }^{14}$ The island is known as "South Talpatty" Island in Bangladesh. It is U-shaped formation with the eastern arm elongated toward the north and had an approxinate area at low-tide of about 2 square miles in 1978, which may have further grown in size in the meantime. It was uninhabited, though fishermen from Bangladesh mainland were observed on the island seasonally during the dry season. The Indian authorities called it "New Moore" island and claim to have notified the

14 Keesing's Contemporary Archives, 18 Sept. 1981, 31090. 
British Admiralty in 1971 about the location of this island. This was at a time when the entire people of Bangladesh were engaged in a life and death struggle during its war of independence. On achieving independence Bangladesh was faced with equally challenging task of rehabilitation and national reconstruction. At no time during this period did the Government of India draw specific attention of the Government of Bangladesh to their claim upon this island as required under international law and practice despite the close and friendly relations existing between the two countries.

The newly emerged island has made all the difference between the countries. Ownership of this infant land mass has been in question for some time. ${ }^{15}$ However, when the Indian Prime Minister visited Bangladesh form 16 to 18 April 1979 the President of Bangladesh took up the matter with him. In the interest of good neighbourly relations Bangladesh proposes a joint survey do dispel any misgivings about the actual location and rightful ownership of the island and thus to peacefully settle this problem as between two neighbours. In demonstrating the friendly relations existing between the two countries and in a spirit of understanding, the Indian Prime Minister in meeting with Bangladesh President agreed to the Bangladesh proposal for a joint survey to determine the location and ownership of the island.

In fact, this commitment to a joint survey was confirmed by the Indian Prime Minister when the Deputy Prime Minister of Bangladesh called on him in New Delhi in the second week of May 1979. Since then the Indian side has been repeatedly requested to expedite the proposed joint survey. The Bangladesh High Commissioner in New Delhi in his message dated 30 May 1980 informed Dacca that he had three meetings in the Indian External Affairs Ministry and that the Indian side had agreed to supply this case more thoroughly before taking up a joint survey.

As regards this island, both Bangladesh and India are still passing through conflict. ${ }^{16}$ Bangladesh lays claims to this island on the assumption that the midstream of the border river Haribhanga flows to the west of the island. But Indian claims it on the assumption that the midstream flows to the east of the island.

Moreover, in March 1980, the Indian daily "Ananda Bazar Patrika" and other West Bengal (India) newspapers carried news mentioning the emergence of second island. Several items were published according to which another island on the estuary of the Haribhanga river was reportedly detected by the Naval Hydrographic survey of India in 1975. It was reported that the state Government of West Bengal called this new island 'Purbashar. From the descriptions of the location of this new island given by the West Bengal Press, it appeared that the island was situated very near to the south Talpatty Island on its western side.

Satellite imageries available in Bangladesh indicated the presence of a low-tide elevation conforming to the location mentioned in the West Bengal (India) press of the 'Purbashar

15 The London Financial Times, 19 May 1981, 4.

16 The London Times, 12 April 1981, 5. 
Island. The satellite photograph sent by the Indian Ministry of External Affairs under their Note of 9 April 1980 to the Bangladesh Ministry of Foreign Affairs also showed a similar low-tide elevation in the midstream of the border river Haribhanga.

Indian Government subsequently denied that there was indeed, a second island and adopted the position that the "New Moore" and 'Purbashar were one and the same Island. ${ }^{17}$ At this stage it is significant to note that all misgivings regarding the location of the newly emerged islands in the estuary of the border river Haribhanga and their rightful ownership could be easily dispelled by a physical joint survey of this area. This would also remove existing confusion over the names and establish facts on the ground regarding the number of islands, their location and ownership.

There seems to be no doubt that the subject matter of the conflict between Bangladesh and India over the newly emerged island is concerned with the issues of fact rather than law.

\section{How to Settle the South Talpatty Dispute?}

The South Talpatty Island has been a big problem both for Bangladesh and India. It is the aim of each country to achieve the island. It is natural for everybody to speak for its own interests. There is nothing to contradict the view that Bangladesh cannot face India while ownership of the island is subject to physical force.

Whatever importance and whatever enthusiasms exist as to the ownership of the island, it is neither Bangladesh nor India can say to have owned the island. Legally, the ownership of the island is to be effected by the boundary of the territorial sea between the two countries. Until the South Talpatty Island is demarcated by the boundary of the territorial sea, there is no scope for any state to assert claims to this island. So long the boundary of the territorial sea will not be determined, assertion of claims to the island will not be effective.

Whatever be the claims and counterclaims by Bangladesh and India to the South Talpatty Island all confusions would be removed, if the territorial sea boundary would be delimited. As a practical consideration, the South Talpatty Island cannot be recalled to be too complicated, because with the delimitation of the territorial sea between the two countries there will be no scope to raise pleas to the acquiring of this island one against the other.

So far Bangladesh and India are going through negotiations for the settlement of maritime boundary disputes. Until now, they have not been successful.

Since islands are emerging in the maritime zones, it can be assumed that with the passage of time Bangladesh and India will have to face much more complicated problems as to the settlement of maritime boundary discutes. Law is not merely a convenient

17 See Ministry of Foreign Affairs, Bangladesh, White Paper on the South Talpatty Island, 26 May 1981. 
device for settlement of disputes. It can sometimes be an effective instrument in a crisis and left out of account at other times. It is useful as a means of settlement only when, and so far as, a society has accepted the rule of law as its way of life.

If Bangladesh and India fail to settle the dispute, it may be required for the United Nations to take measures for the settlement of disputes in order to maintain international peace and security. But questions arise, whether the matter will come to the notice of the United Nations. According to India's notification, disputes arising out of the maritime territory will be treated as lying in the internal jurisdiction of India. ${ }^{18}$ It signifies that no third party settlement can be made effective as long as India does not consent to it or is compelled to do the same. The question of the third party settlement will arise, wehn the situation results in the breach of international peace and security. ${ }^{19}$ If so, the situation will be subjected to the purview of the United Nations.

Whatever be the problem as to be settlement of maritime disputes, there are difficulties for the small and weak country like Bangladesh to bring the matter to the notice of the United Nations against a big and strong counterpart like India. If the maritime boundary dispute between Bangladesh and India is not settled, it may draw the attention of other states who will not only criticise but also blame the big and strong party - India. The reason is that there arises a moral obligation of the states in disputes to take initiatives for the settlement of disputes. This will be applicable both to Bangladesh and India with regard to the maritime boundary disputes. If it is released that a proposal of joint survey is declined, the state declining such survey will be assumed as creating a bar for the settlement of disputes. It seems that both Bangladesh and India should come together for the settlement of maritime disputes.

\section{Reflections}

As a matter of fact, different techniques have been adopted by the coastal states to exercise an extended maritime jurisdiction. From the viewpoint of the developing countries there is no problem for the developed states to exercise extended maritime jurisdiction in order to ensure interests in the seas. As the developed states have capital, technology and expertise, it is therefore favourable for them to monopolize the sea resources. Clearly speaking, as time passed since 1960, science and technology developed

18 Disputes which India considers to be settled subject its internal jurisdiction are related to: (a) the status of its territory or the modification or delimitation of its frontier or any other matter concerning boundaries; (b) the territorial sea, the continental sheld and the margins, the exclusive fishery zone, the exclusive economic zone, and other zones of national maritime jurisdiction including for regulation and control of marine pollution and the conduct of scientific research by foreign vessels; (c) the condition and status of its islands, bays and gulfs and that of the bays and gulfs that for historical reasons belong to it; (d) the airs ace superjacent to its land and maritime territory and (e) the determination and delimitation of its maritime boundaries. See 30(1975-76) ICJ Yearbook 62.

19 See Articles 1 and 24 of the Charter of the United Nations. 
rapidly among the developed nations. Because of such development the developing nations were afraid of access to the resources of the seas beyond national jurisdiction. The developing nations were required to seriously consider it and to take measures to that end they raised claims unitedly for not treating the seabed, ocean floor and subsoil and the mineral resources thereof beyond national jurisdiction subject to the freedom of the high seas doctrine or to the territorial jurisdiction of state or entity of any kind. The final outcome of such attempt is the common heritage doctrine as incorporated in the LOS Convention. The common heritage doctrine appears to deal equitably with the interests of all states. In sea matters within national jurisdiction the common heritage doctrine has no application. Whatever extended maritime jurisdiction is possible for the coastal state the common heritage regime cannot be taken into question.

The United Nations Convention on the Law of the Sea 1982 seems to have incorporated a new regime for the seas but as a practical consideration it has not been successful to curtail the maritime jurisdiction which the coastal states have already been exercising. Because of their capital, technology and expertise it is though favorable for the developed states to extend the seabed jurisdiction but the poor developing countries were not behind in extending this jurisdiction. These states have taken the developed states' attempts as precedent to extend the jurisdiction. Whatever be the reasons for extending the seabed jurisdiction, the very purpose of the poor developing countries was for ensuring legal safeguard of interests to their entirety.

The regime of islands as laid down in Article 121 of the LOS Convention cannot deal with the ownership of new-born islands in the EEZ and on the continental shelf. ${ }^{13}$ If the coastal state regards the island, it should own it by "occupation" criterion. As the island emerging in the sea zone beyond the territorial sea is assumed as a res nullius the first comer will then be entitled to its ownership. Neither the Continental Shelf doctrine nor the EEZ regime can be treated as a security for the coastal state for ownership of the island. Without treating the sea zone in which the island emerges as the part of the coastal state, there is no security for this state to assert claims to the "new-born " island in the EEZ and on the continental shelf. It is a big problem for the small and weak coastal ownership of such island. There may not be surprising that the coastal states in whose maritime zones new islands are emerging will proceed for ensuring the legal security for ownership of the island. Under the circumstances the coastal state will recall the maritime zones as the part of its territory. Its purpose will be to ensure the ownership of the island. In this situation if the ownership of the island is claimed by an alien state, it is the coastal state which will have a strong ground to call the alien state an aggressor. This will enable the coastal state to draw attention of other states and the United Nations.

In the Bangladesh-India situation as to the South Talpatty Island dispute, there arises no question on the ownership of the island. As the South Talpatty Island is in the territorial sea, the ownership of the island in favour of the state in whose territorial sea it emerges is 
unquestioned. The South Talpatty Island dispute will automatically be settled on the delimitation of the territorial sea between Bangladesh and India.

But as a small and weak state it is Bangladesh which has no alternative but to aspire the 200 n.m. EEZ and the continental shelf as part of its territory. Its purpose is to assert claims to the island in these sea zones as part of its territory. In sea matters what legal security the developing countries ensure, it is the small and weak Bangladesh which has no alternative but to ensure similar legal security for its interests.

In the circumstances, it is proposed that Bangladesh should legally be protected from the alien state's claims to the islands, then the EEZ and the continental shelf require to belong to the country. But question arises as to its validity under the existing law of the sea. Otherwise, the country will aspire to regard the 200 n.m. extent as the territorial sea. But the question will be identical in the sense that Bangladesh will have to justify it. In the existence of the United Nations Convention on the law of the Sea 1982, it will not be viable to encourage 200 n.m. to the extent of the territorial sea. From the legal point of view, the LOS Convention cannot safeguard Bangladesh in acquiring the "new-born" island(s) in its EEZ and on the continental shelf against an alien state which acquires it by "occupation". Finally, the small and weak Bangladesh is in a dilemma for claiming ownership to the "new-born" islands in its EEZ and on the continental shelf while it has to challenge the big and strong neighbours. 
parenthood. Parental guardianship and custody is guided by the principle of equality between the two sexes, irrespective of legitimacy or illegitimacy of the child. Explicit provisions will be found further on maintenance, majority, capacity to contract, adoption etc.

The happy and carefree childhood and adolescence Laotians were once said to have enjoyed seem to be long gone since Party and State undertook to pilot the young generation of Laos into a brilliant future along the Laotian path to socialism.

\section{Practice of UNCLOS between Developing Countries with Reference to the Conflict over the South Talpatty Island}

\section{By M. Habibur Rahman}

The law of the sea has developed over the years. The United Nations Convention on the Law of the Sea of 1982 (UNCLOS) is the latest document on the subject. The present international law of the sea is governed by this Convention. The paper deals with the trends of the developing countries in safeguarding their interests in the sea zones within national jurisdiction, and in so doing it has focused on the Convention provisions. Attempts have been made to describe UNCLOS practices of developing countries. Specifically, the study clarifies Bangladesh practice. It deals critically with the problems of deciding ownership of "new-born" islands in the maritime zones beyond the territorial sea. In regard to the conflict on the ownership of the South Talpatty Island the study delves into the details of the issue between Bangladesh and India.

\section{Some Remarks on the Chinese Reform Constitution}

\section{By Manfred Kulessa}

The dialectic relationship between continuity and reform is also to be found in Chinese legal history. The reformers are trying to establish a new legal system of which the Constitution of 1982 is meant to be the cornerstone. After the constitutions of 1949, 1954, 1975, and 1978, a new level of legislative efficacy is envisaged. Changes are expected and may be warranted in the field of economic restructuring.

The Preamble formulates the guidelines of China's policies. The aim is to build a socialist country of high civilisation and highly developed democracy. The Communist Party and the Political Consultative Conference do not enjoy constitutional rank as organs of the state. 